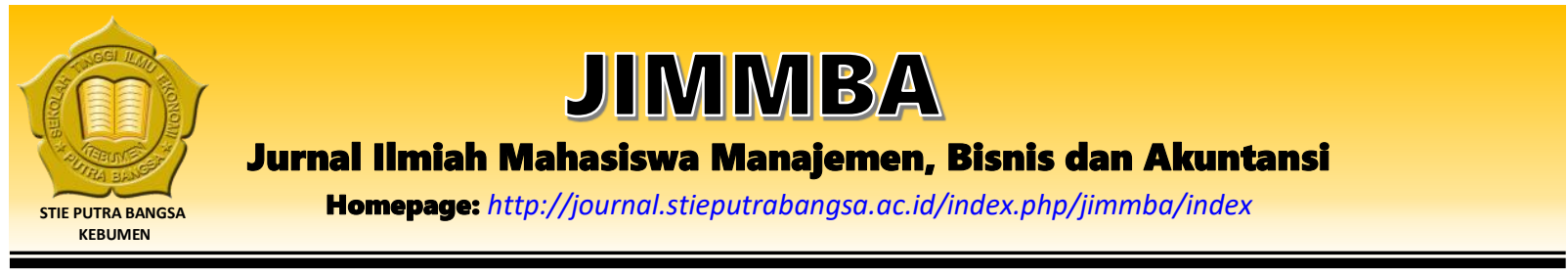

\title{
Pengaruh Penghindaran Pajak Terhadap Struktur Modal dengan Likuiditas sebagai Variabel Mediasi
}

\author{
Chatherine Marpaung ${ }^{1}$, Harlyn Lindon Siagian'2, Francis Hutabarat ${ }^{3}$ \\ 1,2,3 Universitas Advent Indonesia \\ Email: marpaungchatherine8@gmail.com ${ }^{1}$, siagian_unai@yahoo.co.id ${ }^{2}$,fmhutabarat@unai.edu ${ }^{3}$
}

\author{
ARTICLE INFO \\ Article History: \\ Received: September 29th \\ 2020 \\ Accepted: October 20st 2020 \\ Published: October 22nd 2020 \\ Keywords: \\ Penghindaran Pajak, \\ Likuiditas, Struktur Modal
}

\begin{abstract}
Adapun manfaat pembuatan berdasarkan pada penelitian ini ialah agar memberikan bukti bahwa adanya pengaruh penghindaran pajak pada struktur modal dengan current ratio sebagai variabel mediasi terhadap badan yang listing di Bursa Efek Indonesia periode 2015-2019 pada subsektor industri barang konsumsi, dan diharapkan juga agar mendapatkan bukti empiris mengenai peran kebijakan hutang dalam memoderasi pengaruh penghindaran pajak pada struktur modal. Penulis membuat penelitian ini dengan memakai analisis deskriptif yang dibantu dengan menggunakan aplikasi SPSS. Data penelitian menggunakan laporan keuangan berupa data sekunder dari 15 Perusahaan yang listing di BEI dalam periode 2015-2019 pada Subsektor makanan dan minuman. Uji kelayakan model, Uji Hipotesis, Uji Determinasi merupakan analisis data yang diambil dalam penelitian. Hasil uji model 1 menunjukkan bahwa penghindaran pajak tidak memiliki pengaruh yang signifikan pada struktur modal. Hasil uji model 2 didapati dimana antara Current Ratio dengan struktur modal terdapat pengaruh yang signifikan. Penghindaran pajak pada Struktur Modal dan Likuiditas sebagai variabel mediasi.
\end{abstract}

\section{Pendahuluan}

Setiap perusahaan pasti memerlukan dana (modal) untuk setiap keputusan investasinya guna mengembangkan usahanya dimana modal tersebut dapat berupa laba ditahan dengan menggunakan modal sendiri maupun modal asing, dalam menerbitkan saham baru perusahaan dapat melakukannya dengan cara memakai ekuitas (saham) atau juga dapat menggunakan hutang apabila modal sendiri yang berupa laba ditahan tersebut tidak mencukupi.

Menurut Ilmiani \& Sutrisno (2014) jika suatu perusahaan mempunyai harga saham yang rendah sehingga semakin rendah pulalah nilai perusahaan tersebut sebaliknya jika harga saham di satu perusahaan semakin tinggi sehingga dapat dianggap nilai perusahaan tersebut semakin tinggi. Tinggi rendahnya nilai suatu perusahaan bisa berdampak pada pemilik saham pada saat mereka akan membuat keputusan apakah mereka akan tetap mau atau tidak dalam 
mempertahankan investasi mereka. Juga para kandidat penanam modal akan terdorong untuk menanamkan modal mereka pada perusahaan yang mereka inginkan.

Cara yang bisa dilakukan dalam menghindari pajak secara resmi tanpa harus melanggar aturan-aturan perpajakan adalah dengan menjalankan Penghindaran pajak. Dari sisi hukum pajak, penghindaran pajak bukanlah sesuatu hal yang dilarang meskipun dari kantor pajaknya selalu mendapat perhatian yang kurang baik karena diperkirakan mempunyai pengaruh buruk atau anggapan yang kurang nasionalis. Suandy (2011) mengatakan dimana yang disebut dengan penghindaran pajak merupakan rekayasa tax affairs yang tetap ada pada garis yang ditentukan dalam perpajakan (lawful). Tax avoidance berlawanan dengan jiwa undang-undang tetapi bisa terjadi dalam ketentuan undang-undang. Dengan menggunakan penghindaran pajak sebagai penghematan pajak itu dapat berguna untuk menekan kewajiban pajak, dengan memanfaatkan ketentuan perpajakan secara resmi.

Masalah pembiayaan yang dimiliki badan sangat berhubungan terhadap struktur modal. Struktur modal (capital structure) merupakan pembiayaan badan secara terus-menerus dalam jangka waktu panjang yang diwakilkan kepada ekuitas saham biasa, hutang, serta saham preferen (Van Horne dan Wachowicz 2013). Capital structure merupakan gabungan dan bagian dari badan guna mencapai keperluan pembiayaannya (Masnoon dan Saeed 2014). Untuk mengembangkan kemampuan sebagai hal ekspansi operasional perusahaan, perkembangan proyek, serta capital expenditure perusahaan menggunakan pendanaan. Pendanaan perusahaan bisa bersumber dari eksternal perusahaan maupun internal perusahaan. Pendanaan eksternal bisa berbentuk saham maupun hutang baik itu jangka pendek maupun dalam jangka panjang. Modal internal bisa berupa penyertaan kepemilikan perusahaan dan dapat juga berupa retained earning (laba perusahaan). Menurut Verena dan Haryanto (2013) dalam penelitian mereka menyebutkan bahwa Likuiditas dan struktur modal memiliki dampak yang negatif. Juga dalam pengamatan yang dilaksanakan Sheikh dan Zongjun (2011) menunjukkan bahwa antara Likuiditas dan struktur modal terdapat pengaruh negatif dan signifikan.

(Brigham dan Houston 2013) mengatakan dimana kinerja badan maupun nilai perusahaan dapat ditingkatkan degan cara penggunaan struktur modal secara tepat. Nilai perusahaan akan meningkat dengan sendirinya di pasar modal apabila perusahaan mampu meningkatkan kinerja perusahaan. Dalam pengamatan yang dilaksanakan Rahyuda, Saraswathi, serta Wiksuana (2016) disebutkan diamana Struktur modal adalah alat untuk memperbaiki produktivitas serta kinerja badan yang bisa mengembangkan nilai suatu perusahaan. Novitasari (2017) dan Widayanti et al. (2016), berdasarkan penelitian mereka menyebutkan dimana pajak tidak adanya hubungan kepada struktur modal namun pada arah yang positif. Pajak mempunyai hubungan pada struktur modal namun pada arah yang positif, Primantara dan Dewi (2016), Budiono dan Septiani (2017). Sedangkan Pratheepan dan Banda (2016) menjelaskan bahwa pajak mempunyai dampak negatif pada struktur modal.

Lim (2010) dalam penelitiannya mendukung teori trade-off yang menyebutkan bahwa substitusi dari penggunaan hutang merupakan upaya untuk menekan pajak sebagaimana tax avoidance serta tax shelter. 


\section{Kajian Teori dan Telaah Literatur}

\section{Penghindaran Pajak}

Penghindaran pajak dapat diartikan sebagai suatu desain penghindaran pajak yang bertujuan untuk menekan atau bahkan menghapuskan beban pajak dengan menggunakan celah (loophole) syarat perpajakan suatu negara. Secara persepsi, sketsa penghindaran pajak pada dasarnya bersifat resmi atau sah-sah saja karena tidak bertentangan dengan syarat pajak. Pada Pasal 1 UU No. 28 Tahun 2007 disebutkan pengertian pajak yaitu: "Pajak merupakan pemberian masyarakat untuk bagian pemerintah yang terutang oleh badan maupun perseorangan dimana karakternya yang wajib berdasarkan peraturan undang undang yang berlaku, serta bukan mengharapkan adanya imbalan langsung yang dapat dipergunakan sebagai keperluan negara untuk kemakmuran yang sebesar-besarnya. Upaya yang dijalankan oleh satu badan dalam meminimalkan biaya pajak yang semestinya diberikan oleh badan dalam menjalankan implementasi yang resmi serta sesuai dengan syarat yang berlaku dalam perpajakan disebut sebagai Tax Avoidance (Adityamurti dan Ghozali, 2017). Kurniasih dan Sari (2013), dalam penelitiannya menyebutkan bahwa penghindaran pajak merupakan pengendaalian untuk menghilangkan atau meminimalkan kewajiban pajak dengan cara memperhitungkan dampak yang dapat diakibatkan oleh pajak, serta tidak menjadi kesalahan terhadap pajak oleh karena upaya wajib pajak agar dapat mengurangi, meringankan serta meminimalkan beban pajak dilaksanakan dengan aturan yang tampak mungkin oleh undangundang pajak. Tujuan suatu perusahaan menyelenggarakan tax avoidance ialah untuk mengurangi atau menekan kewajiban yang seharusnya dibayar oleh perusahaan. Jika suatu perusahaan menjalankan penghindaran pajak maka itu berarti nilai ETR perusahaan tersebut semakin rendah.

Penghindaran pajak dapat diukur dengan menggunakan rumus CASH ETR :

$$
\text { CASH ETR }=\frac{\text { pembayaran pajak }}{\text { laba sebelum pajak }}
$$

\section{Struktur Modal}

Struktur modal adalah uraian dari penanggungan tetap perusahaan yang berlaku dari hutang jangka panjang maupun dana pribadi. Jika hutang yang sebenarnya (realisasi) dengan posisi dibawah target, maka hutang harus diperbanyak. Saham perusahaan harus dijual apabila rasio utang sudah melebihi target. Apabila terjadi kekurangan (deficit) pada pendanaan dari modal sendiri pada suatu perusahaan, sehingga harus dilakukan estimasi pendanaan. Saleem, et al. (2013) dalam penelitiannya mengamarkan dimana struktur modal mempunyai dampak negatif pada perkembangan badan. Berdasarkan pengamatan yang dilaksanakan oleh Bayrakdaroglu, et al (2013) mengungkapkan dimana pajak serta non-debt shield mempunyai pengaruh positif terhadap struktur modal.

Namun pengamatan yang diteliti Pratheepan dan Banda (2016) memberikan pernyataan dimana pajak mempunyai dampak negatif pada struktur modal. Firmansyah (2016) pun mengungkapkan pada penelitiannya dimana perbandingan badan tidak mempunyai dampak pada struktur modal namun pada arah yang negatif. Tetapi Novitasari (2017) dan Widayanti et al. (2016), mengungkapkan dimana pajak tidaklah memiliki pengaruh pada struktur modal namun dengan arah yang positif. Dalam hal ini, Primantara dan Dewi (2016), Budiono dan Septiani (2017) juga memberikan pernyataan dimana pajak mempunyai dampak pada struktur modal namun pada arah positif. 
Berdasarkan pengamatan ini Struktur modal diukur memakai Debt to Equity Ratio (DER).

$\mathrm{DER}=\frac{\text { TOTAL HUTANG }(\text { LIABILITIES) }}{\text { EQUITAS(EQUITY })}$

\section{Likuiditas}

Debt to Equity Ratio atau Current Ratio yang cepat serta tepat diinginkan mampu menambah keuntungan pada perusahaan. Rasio Likuiditas diproksikan oleh Current Ratio. Kasmir (2017), dalam penelitiannya mengungkapkan bahwa Current Ratio merupakam suatu rasio sebagai alat penimbang kemampuan suatu badan pada pencapaian hutang dengan aktiva lancar. Rasio lancar merupakan rasio penimbang perusahaan melalui proses pembayaran semua hutang-hutang dalam perusahaan yang harus dilunasi. Hery (2015) berpendapat bahwa, rasio yang mencerminkan kesanggupan badan ketika mematuhi utang jangka pendeknya yang akan jatuh tempo adalah yang dikenal dengan Likuiditas. Profitabilitas memperkirakan level profit yang didapatkan oleh perusahaan. Selain mempunyai tujuan untuk mencari tahu kesanggupan perusahaan saat memperoleh laba sepanjang periode yang sudah ditentukan, tujuan dari rasio ini pula adalah untuk memperkirakan level efisiensi dari manajemen saat melaksanakan operasional perusahaan. Rasio yang selalu dipakai dalam mengukur modal dan hutang, yang bisa menutup hutang-hutang kepada pihak luar adalah Debt to Equity Ratio (Harahap, 2013). Adapun rumus current ratio adalah :

$$
C R=\frac{\text { current assets }}{\text { current liabilities }}
$$

\section{Penghindaran Pajak dan Struktur Modal}

Penghindaran pajak mengakibatkan perusahaan-perusahaan besar bisa menjatuhkan total pajak yang akan ditanggungnya, maka kekayaan mereka akan bertambah. Sehingga akan mengurangi distribusi yang diterima masyarakat yang kurang mampu atas kekayaan harta wajib pajak berdasarkan program pemerintah. Oleh karena itu, tax avoidance akan mengurangi kompetensi negara dalam menekan kemiskinan, kelaparan dan bahkan menghambat meningkatnya pengembangan mutu sumber daya manusia dan daya produksi makanan, khususnya pada negara miskin dan berkembang. Dalam penelitian (Eka dan Muid, 2017) mengungkapkan bahwa meningkatnya nilai perusahaan dapat diperoleh dari kegiatan tax avoidance yang dijalankan perusahaan, karena akan menambah laba (profit) yang diterima oleh perusahaan, maka bisa mendukung untuk mengoptimalkan nilai pada perusahaan tersebut. Namun aksi semacam ini dapat manimbulkan masalah keagenan antara pemegang saham dan manajer. Karena tindakan penghindaran pajak membutuhkan dana yang wajib diberikan badan maka bagian badan wajib memperhitungkan biaya dan keuntungan yang akan diterima (Ardiyanto dan Herdiyanto 2015). Sehingga penulis menggunakan Cash Effective Tax Ratio sebagai penunjuk dalam mengukur tax avoidance. Yang mana laba sebelum pajak dibagi dengan kas yang dikeluarkan untuk biaya pajak dimana diinginkan sanggup menjelaskan secara aktif target pajak perusahaan itu merupakan Cash Effective Tax Ratio. Apabila Cash Effective Tax Ratio memiliki nilai makin besar sehingga akan membuat tingkat penghindaran pajak semakin kecil, dan begitu juga sebaliknya apabila penghindaran pajaknya semakin tinggi itu berarti nilai terhadap Cash Effective Tax Ratio tersebut makin kecil, hal ini diungkapkan dalam penelitian yang dilaksanakan (Ilmiani dan Sutrisno 2014). Dalam pengamatan terdahulu telah dibahas seputar dampak penghindaran 
pajak dan struktur modal. Berdasarkan pengamatan yang dilaksanakan Pratheepan dan Banda (2016) mengungkapkan dimana adanya pengaruh negatif antara pajak pada struktur modal. Pajak tidak mempunyai dampak pada struktur modal namun dengan arah yang positif, Novitasari (2017) dan Widayanti et al. (2016). Primantara dan Dewi (2016), Budiono dan Septiani (2017) juga memberikan pernyataan bahwa adanya pengaruh pajak terhadap struktur modal namun dengan arah yang positif. Dari uraian tersebut dapat dirumuskan :

$\mathbf{H}_{\mathbf{1}}$ : Adanya pengaruh signifikan antara penghindaran pajak dan struktur modal

\section{Likuiditas dan Stuktul Modal}

Kesanggupan satu badan ketika mencapai hutang jangka pendeknya melalui current assets yang dimiliki oleh perusahaan disebut sebagai Likuiditas. Sehingga apabila semakin tinggi likuiditas pada suatu perusahaan sehingga akan semakin tinggi pula current asset nya dibandingkan dengan current liabilities yang dimiliki perusahaan tersebut. kesanggupan perusahaan ketika memenuhi hutang jangka pendeknya yang sudah jatuh tempo hal itu juga disebut sebagai Likuiditas. Pada umumnya Rasio yang menunjukkan adanya hubungan antara Current Asset dan Current Liabilities adalah Current Ratio yang dipakai menjadi suatu alat untuk menghitung Likuiditas. Badan yang biasanya dipercaya pasar mempunyai kualitas likuiditas yang besar adalah perusahaan yang mampu dalam menjaga tingkat likuiditasnya, hal itu bisa dinilai dari kinerja perusahaan yang baik. Likuiditas perusahaan yang besar menandakan bahwa perusahaan itu mempunyai dana yang cukup dalam membayar biaya operasional perusahaan tanpa harus meningkatkan utang. Likuiditas yang besar tidak menjamin kuatnya keadaan keuangan suatu perusahaan, ini didasarkan oleh tingginya aset yang dicairkan secepatnya untuk membayar kewajibannya. Apabila derajat likuiditas satu badan memiliki pengaruh atas tinggi rendahnya struktur modal badan tersebut maka ini artinya Likuiditas mempunyai pengaruh signifikan pada struktur modal. Anita Dwilestari (2010) dan Dwi Ema Putra serta I Ketut Wijaya Kesuma (2014) menjelaskan bahwa jika aktiva lancar pada satu perusahaan lebih besar daripada hutang yang harus dipenuhi maka ini artinya perusahaan tersebut memiliki likuiditas yang besar sehingga apabila jumlah struktur modal pada satu badan mengalami penurunan itu dikarenakan likuiditas perusahaan tersebut meningkat. Dari uraian diatas dapat disimpulkan :

$\mathbf{H}_{\mathbf{2}}$ : Adanya pengaruh signifikan antara likuiditas dengan struktur modal

\section{Metode Penelitian}

\section{Variabel penelitian}

Melalui pengamatan ini penulis mengelola tiga variabel, yang mana ada dua variabel bebas serta satu variabel terikat. Komponen pada variabel independent yaitu Penghindaran pajak dan dengan menggunakan likuiditas sebagai variabel mediasi yang diukur menggunakan current ratio, sedangkan struktur modal digunakan sebagai variabel terikat. pengamatan ini dilaksanakan terhadap badan yang listing di BEI pada periode 2015-2019 dalam bidang subsektor industri barang konsumsi. 


\section{Populasi dan Sampel}

Populasi dalam pengamatan ini diambil dari perusahaan yang listing di BEI pada subsektor industri barang konsumsi. Jumlah populasi adalah sebanyak 15 perusahaan dengan jumlah sampel sebanyak 75 data yang diolah. Berikut merupakan nama dan kode perusahaan : Wismilak Inti Makmur Tbk (WIIM), HM Sampoerna Tbk (HMSP), PT. Indonesian Tobcco Tbk (ITIC), Bantoel International Investama Tbk (RMBA), Gudang Garam Tbk (GGRM), PT. Integra Indocabinet Tbk (WOOD), Langgeng Makmur Industri Tbk (LMPI), Kedaung Indah Can Tbk (KICI), PT. Chitose Internasional Tbk (CINT), Unilever Indonesia Tbk (UNVR), Mandom Indonesia Tbk (TCID), Mustika Ratu Tbk (MRAT), PT. Kino Indonesia Tbk (KINO), Martina Berto Tbk (MBTO), Akasha Wira International Tbk (ADES).

\section{Sumber data}

Melalui penelitian ini penulis memakai analisis deskriptif dengan memilih data dari perusahaan yang listing di BEI pada subsektor industri barang konsumsi sebagai penyedia informasi laporan keuangan pada periode 2015-2019.

\section{Analisis data}

Analisis statistik data yang dipakai yaitu koefisien determinasi, signifikan test, regresi analisis. Pengolahan data-data pengkajian ini dibantu memakai perangkat lunak SPSS.

\section{Hasil dan Pembahasan}

\section{Hasil Uji kelayakan model (Uji F)}

Hasil uji signifikan menunjukkan pada model 1 bahwa antara ETR terhadap struktur modal tidak mempunyai pengaruh signifikan. Ini bisa diketahui dari nilai F-test 1.513 dan nilai significant 0.223 pada $\alpha=0.05$ atau $5 \%$. Sedangkan pada model 2 , ditemukan bahwa dengan adanya mediasi CR maka ditemukan pengaruh ETR, CR terhadap struktur modal adalah significant dengan tingkat signifikan 0.039 pada $\alpha=0.05$ atau $5 \%$ dengan F-test 3.394.

\section{Hasil Uji Hipotesis (Uji-t)}

Hasil uji signifikan menunjukkan bahwa diantara variable independent maka terlihat bahwa pada model 1 tidak ada pengaruh signifikan pada variable ETR terhadap struktur modal dengan nilai signifikan 0.223 pada level signifikan 5\%. Sedangkan pada model 2, didapati dengan adanya mediasi CR, didapati bahwa ETR dan struktur modal tetap memiliki pengaruh yang tidak signifikan yaitu 0.223 pada level signifikan 5\%. Dan terkait CR dan Struktur modal didapati adanya pengaruh yang signifikan dengan level signifikan 0.026 pada level signifikan 5\%. Dengan demikian keberadaan CR sepenuhnya memediasi pengaruh ETR dan struktur modal. Adapun model regresi yang didapat adalah:

$$
\begin{aligned}
& \mathrm{DER}_{1}=1.335-1.282 \mathrm{ETR}_{1} \\
& \mathrm{DER}_{2}=2.084-1.025 \mathrm{ETR}_{2}-.343 \mathrm{ROE}_{2}
\end{aligned}
$$




\section{Hasil Uji Determinasi $\left(R^{2}\right)$}

Pada tabel uji determinasi memperlihatkan dimana pada model 1 nilai R-Square adalah senilai .021 yang berarti kontribusi ETR terhadap perubahan pada struktur modal adalah sebesar 2.1\%. Terkait model 2, ditemukan bahwa dengan mediasi CR maka ditemukan kontribusi ETR serta CR pada perubahan pada struktur modal menjadi sebesar $8.7 \%$ dan didapati perubahan dalam nilai R-Square change sebesar 0.066 atau $6.6 \%$.

\section{Pembahasan}

Pada penelitian ini didapati bahwa hipotesa 1 menyatakan dimana ETR tidak berpengaruh signifikan pada Struktur modal. ETR merupakan rasio tingkat pembayaran pajak perusahaan. Berdasarkan hasil uji menjelaskan dimana tidak adanya pengaruh signifikan antara ETR dan Struktur modal. Dalam pengamatan yang dilaksanakan oleh Bayrakdaroglu (2013) mengungkapkan dimana pajak mempunyai pengaruh signifikan terhadap struktur modal. Berbeda pada pengamatan yang dilaksanakan oleh Pratheepan dan Banda (2016) mengungkapkan dimana pajak mempunyai pengaruh negatif pada struktur modal.

Pada penelitian ini didapati bahwa hipotesa 2 menunjukkan dimana CR berpengaruh signifikan pada Struktur modal. CR merupakan rasio yang menghitung tingkat keuntungan badan perusahaan dan banyak digunakan oleh para investor. Berdasarkan hasil uji mengatakan bahwa antara CR dan Struktur Modal ada pengaruh yang signifikan pada model 2 untuk level signifikan 5\%, hal ini didukung berdasarkan pengamatan yang telah dilaksanakan oleh Anita Dwilestari (2010) dan Dwi Ema Putra serta I Ketut Wijaya Kesuma (2014). Namun terdapat hasil yang menunjukkan perbedaan dengan pengamatan yang dilaksanakan oleh Handayani (2011) yang menjelaskan dimana likuiditas tidak mempunyai pengaruh signifikan pada struktur modal.

\section{Penutup dan Saran}

\section{Simpulan}

Setelah di uji secara parsial ataupun secara simultan melalui SPSS, dapat disimpulkan dari hipotesa 1 bahwa penghindaran pajak tidak mempunyai pengaruh signifikan pada struktur modal pada perusahaan yang listing di BEI pada periode 2015-2019 pada subsektor makanan dan minuman. Dan dari hipotesa 2 didapati bahwa likuiditas mempunyai pengaruh signifikan pada struktur modal dalam perusahaan yang listing di BEI tahun 2015-2019 pada subsektor makanan dan minuman.

\section{Saran}

Saran penulis untuk peneliti berikutnya agar menggunakan variabel lain yang menjadi mediasi dalam penelitian yang akan diteliti. Juga diharapkan agar dapat meneliti lebih banyak lagi mengenai faktor-faktor yang mempunyai pengaruh terhadap tax avoidance serta semakin teliti saat melaksanakan penelitian yang dimulai dari tahun pengamatan, rentan window yang lebih lama, pemilihan ukuran masing-masing variabel, serta pemilihan populasi dalam penelitian yang lebih universal. Hal itu bertujuan untuk menghindari kemungkinan terjadinya penyimpangan hasil terhadap teori yang ada. 


\section{Referensi}

Adityamurti, E., \& Ghozali, I. (2017). Pengaruh penghindaran pajak dan biaya agensi terhadap nilai perusahaan. Diponegoro Journal of Accounting, 6(3), 124-135.

Bayrakdaroglu, A., Ege, I., \& Yazici, N. (2013). A panel data analysis of capital structure determinants: Empirical results from Turkish capital market. International Journal of Economics and Finance, 5(4), 131-140.

Brigham, E. F., \& Houston, J. F. (2013). Dasar-Dasar Manajemen Keuangan. Jakarta: Salemba Empat.

Eka, P., \& Muid, D. (2017). Analisis Pengaruh Tata Kelola Perusahaan dan Penghindaran Pajak Terhadap Nilai Perusahaan (Studi Empiris Pada Perusahaanpublik Yang Tercatat Di Bursa Efek Indonesia Tahun 2014-2015). Doctoral Dissertation. Universitas Diponegoro.

Ghozali, I. (2011). Aplikasi Analisis Multivariat dengan Program SPSS. Edisi Lima. BadanPenerbit Universitas Diponegoro. Semarang.

Harahap, S. S. (2013). Analisis Kritis atas Laporan Keuangan. Jakarta: Raja Grafindo Persada.

Herdiyanto, D. G., \& Ardiyanto, M. D. (2015). Pengaruh Tax Avoidance Terhadap Nilai Perusahaan. Doctoral Dissertation, Universitas Diponegoro.

Hery, S. E. (2015). Analisis Laporan Keuangan Pendekatan Rasio Keuangan. Bandung, Penerbit: CAPS.

Horne, J. C. V., \& Wachowicz, J. M. (2012). Prinsip-Prinsip Manajemen Keuangan. Jakarta: Salemba Empat.

Ilmiani, A., \& Sutrisno, C. R. (2015). Pengaruh Tax Avoidance Terhadap Nilai Perusahan Dengan Transparansi Perusahaan Sebagai Variabel Moderating. Jurnal Ekonomi dan Bisnis, 14(1), 30-39.

Irman, F. F. (2016). Analisis Struktur Aktiva, Ukuran Perusahaan dan Growth Opportunity yang Mempengaruhi terhadap Struktur Modal dengan Total Hutang sebagai Variabel Moderating pada Sektor Kabel di Bei. Jurnal Wira Ekonomi Mikroskil: JWEM, 6(2), 193-204.

Kurniasih, T., Sari, R., \& Maria, M. (2013). Pengaruh return on assets, leverage, corporate governance, ukuran perusahaan dan kompensasi rugi fiskal pada tax avoidance. Buletin Studi Ekonomi, 18(1).

Lestari, A. D. (2010). Pengaruh struktur aktiva, pertumbuhan, dan likuiditas terhadap struktur modal perusahaan. Jurnal Riset Akuntansi dan Keuangan, 6(2), 155-165.

Lim, Y. (2011). Tax avoidance, cost of debt and shareholder activism: Evidence from Korea. Journal of Banking \& Finance, 35(2), 456-470.

Masnoon, M., \& Saeed, A. (2014). Capital Structure Determinants of KSE Listed Automobile Companies. Masnoon \& Saeed (2014)" Capital Structure Determinants of KSE Listed Automobile Companies" European Scientific Journal, May edition, 10(13), 451-461.

Novitasari, C., \& Mildawati, T. (2017). Faktor-Faktor Yang Mempengaruhi Struktur Modal Perusahaan Manufaktur. Jurnal Ilmu dan Riset Akuntansi (JIRA), 6(7), 1-21. 
Pratheepan, T., \& Yatiwella, W. B. (2016). The determinants of capital structure: Evidence from selected listed companies in Sri Lanka. International Journal of Economics and Finance, 8(2), 94-106.

Primantara, A. N. A. D. Y., \& Dewi, M. R. (2016). Pengaruh likuiditas, profitabilitas, risiko bisnis, ukuran perusahaan, dan pajak terhadap struktur modal. E-Jurnal Manajemen Universitas Udayana, 5(5), 2696-2726,

Saleem, F., Rafique, B., Mehmood, Q., Irfan, M., Saleem, R., Tariq, S., \& Akram, G. (2013). The determination of capital structure of oil and gas firms listed on Karachi stock exchange in Pakistan. Interdisciplinary journal of contemporary research in business, 4(9), 225-235.

Saraswathi, I. A. A., Wiksuana, I. G. B., \& Rahyuda, H. (2016). Pengaruh risiko bisnis, pertumbuhan perusahaan, struktur modal terhadap profitabilitas serta nilai perusahaan manufaktur. E-Jurnal Ekonomi dan Bisnis Universitas Udayana, 5(6), 17291756.

Sari, D. V., \& Haryanto, A. M. (2013). Pengaruh Profitabilitas, Pertumbuhan Aset, Ukuran Perusahaan, Struktur Aktiva Dan Likuiditas Terhadap Struktur Modal Pada Perusahaan Manufaktur Di Bursa Efek Indonesia Tahun 2008-2010. Doctoral Dissertation, Universitas Diponegoro.

Seftianne, S., \& Handayani, R. (2011). Faktor-faktor yang mempengaruhi struktur modal pada perusahaan publik sektor manufaktur. Jurnal Bisnis dan Akuntansi, 13(1), 39-56.

Sheikh, N. A., \& Wang, Z. (2011). Determinants of capital structure. Managerial Finance, 37(2): 117-133.

Suandy, E. (2011). Perencanaan pajak, edisi 5. Jakarta: Salemba Empat. 